\title{
SUPPORT OF INNOVATIONS IN MAIN DEVELOPMENT STRATEGIES OF REGIONAL CAPITALS IN THE CZECH REPUBLIC
}

\author{
Martin Habuda, Ladislav Kudláček, Aleš Gregar
}

\begin{abstract}
Innovation and their support by the public sector are currently in focus of intensive research in the area of regional development. Innovation capacity is considered as the main source of competitiveness of regions. The role of regional governments is emphasized in concepts such as Regional Innovation Systems and Triple Helix. Municipalities represent a lower level of government. In some cases, depending on the country's public administration system and the size of the municipality, these entities may be very strong participants for regional governments. Such municipalities naturally have the potential to act as important participants in regional innovation systems, and they should clarify these roles in their strategic documents. The paper focuses on the topic of innovations support within the main development strategies of regional capitals in the Czech Republic. It provides findings on how the topic of innovations support is included in the structures of these strategies, identifies typical aims, measures, activities and instruments for supporting innovation, assesses the complexity of innovations support declared in these strategies and draws a conclusion on the importance of this topic in terms of regional capitals. Research is based on the scientific method of text document analysis. The main development strategies of twelve regional capitals in the Czech Republic were analysed by this method. The documents were gathered for the research at the turn of September and October 2019. The results of the research show that innovations support represents an important topic in the main development strategies of the regional capitals in the Czech Republic. At the same time, methodological inconsistencies in the elaboration of the examined strategies were identified, especially in terms of structure, terminology, and degree of detail.
\end{abstract}

Keywords: strategic planning, innovations support, regional development, local development, competitiveness, regional innovation system

\section{INTRODUCTION}

The paper interconnects the topic of strategic planning of regional development at the municipal level with the topic of innovation support. Concerning this, the introduction part is divided into three sub-parts. The first part provides an overview of the strategic planning of regional development in the Czech Republic on the level of municipalities. The second part deals with theoretical bases in the field of innovation support. The third part summarizes current situation in the field of support of innovation in the framework of strategic planning in the Czech Republic at the regional and municipal level.

\subsection{Strategic planning of regional development in the Czech Republic at municipality level}

According to the one of the most respected definitions by Bryson (2011), the strategic planning is "deliberative, disciplined approach to producing fundamental decisions and actions that shape and guide what an organization (or other entity) is, what it does, and why." The purpose is to help managers and leaders overcome with the biggest challenges and problems an organization face; this ability of strategic planning stems from its complexity which comprises of a wide and detailed analytic view of the organization and its internal and external environment, identifying 
key issues and challenges, finding possible ways how to resolve the issues and the challenges and choosing the best from them; and it all is done in the deliberative way with the participation of key stakeholders (Bryson, 2011). Vozáb (1999) points out that strategic planning is considered as a very universal method, both from the types of planning entities and from the territory or the thematic focus, which the plans deal with.

With the growth of the complexity of relations within society, the importance of municipalities' strategic planning also grows. "Strategic planning represents the only management tool, that allows embracing the issue of evolution, resp. development of a given area, complexly and effectively guide it within the sustainable development principles" (Habuda, 2013). Bryson (2011) shows dramatically growing amount of dynamic changes in the society when the survival of an organization, including an organisation in the public sector, is not easy in such conditions; he accentuates that organisations of the public sector will have to think, act and learn strategically more than ever before.

The situation of strategic planning at municipality level in the Czech Republic has been the subject of several researches in the past. For example, according to an extensive questionnaire survey conducted in $2015,82.4 \%$ of municipalities have or are preparing their development strategic plans (Ježek et al., 2015). Similarly, Grebeníček et al. (2013) identified that of the 13 Czech regional capitals, 12 have approved a strategic development plan. At the same time, there is a very rich offer of methodologies and procedures on the topic of preparing strategic plans for towns and municipalities (Ježek, 2014).

However, there are many problems in this area. For example, strategic planning motivated primarily by efforts to obtain subsidies from EU funds brings about another complication in the form of the frequent occurrence of non-systemic strategies (Ježek et al., 2015). Regarding the quality of municipal planning documents and the possibilities of their mutual comparison, the authors point to considerable terminological and methodological inconsistencies of strategic municipal documents, their comparison is then more complex (Grebeníček \& Hájek, 2013; Grebeníček et al., 2013). Ježek et al. (2015) summarizes that the centre of the strategic documents of the municipalities is in an analysis rather than in setting a long-term conception; nevertheless the analysis is presented by broad sums of quantitative data but there are no deeper analytical results concluded from it, there are no consequences and connections explored, creative methods are used much less; though widely accepted, the analyses show superficial character. They reveal an overly wide and general span in the proposal parts of the strategic documents, apparently motivated by the effort to cover all of the areas where available funding sources can be expected; prioritizing the proposals and plans usually lacking. They conclude that the plans are broadly covered lists rather than definite strategies, in which this type of conception is in contradiction with the basic conditions of the strategic planning. Despite their findings regarding insufficient prioritization, Řehoř (2015), who observed strategies of small settlements and microregions in the region of South Bohemia, identified a relatively high share of strategies that have systematically set their prioritization of proposals and plans.

There are also considerable problems in the process area. The rate of the participation of

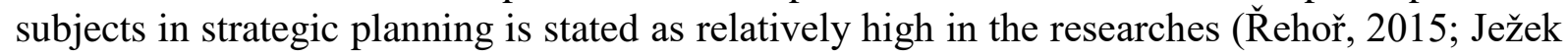
et al., 2015). However, its ability to coordinate various interests and the needs of the subjects falls considerably behind the theoretical preconditions (Slach \& Ježek, 2015). The implementation level of the strategies has a very weak position, the settings of the implementation processes is totally missing or is very superficial and executed ineffectively in most of the strategic documents, there is no set of indicators and regulations for evaluating of the documents, action plans are not prepared (Ježek et al., 2015; ̌̌ehoř, 2015). The efficiency 
of the implementation processes is also lowered by a weak interconnection of planning and budgeting by the municipalities (Grebeníček \& Hájek, 2013; Grebeníček et al., 2013).

This clearly shows that the planning culture in the Czech Republic is not in good condition. Ježek (2014) summarizes that local planning reality does not steam from the theoretical level, the basic political expectations are not fulfilled, and it is a "planning for planning". Novák (2010) even talks about frequent managerial failures in this context. Researchers generally share a negative assessment of the situation, but in some aspects there are indications of positive development.

\subsection{Innovations and instruments to support them}

Innovations and their support by the public sector are currently the focus of intensive research in the area of regional development. Innovation capacity is considered as the main source of competitiveness among the regions.

The prerequisite for creating innovations is appropriate knowledge, as part of an experience or as resulting from a research process, as well as the ability to learn. Knowledge according to Truneček (2004) represents "purposeful coordination of action" and "Ability (art) to do something". However, creating knowledge and the learning process are not an isolated matter within a particular organization, but on the contrary show strong spatial contexts, represented mainly by a network of relationships in its vicinity, as Malmberg (1997) states, for example, when they gain considerable attention in national and regional competitiveness research. Many authors speak about the diffusion of innovation in this context. Differences in the ability to learn and innovate are seen as an essential mechanism for differentiating of the economic development of regions (Maskell, 1998). For example, several studies and researches have shown a strong spatial concentration in high-tech industries.

Various institutional frameworks and concepts have been developed to support the creation and diffusion of knowledge and innovations. Clusters and regional innovation systems have become the most popular ones, which are now an integral part of the political agenda in the European Union.

The concept of regional innovation systems was introduced in the early 1990s by geographer Philip Cooke (Cooke, 1992). Subsequently, this concept has been developed by several other authors and continues to receive considerable attention from the scientific community. The concept of regional innovation systems is both an analytical framework for the research of the competitiveness and innovation performance of individual regions, as well as an instrument for the systematic support of learning in a given region. The main idea of regional innovation systems is that targeted support for the competitiveness of companies is an essential complement to existing spontaneous and accidental synergies resulting from agglomeration benefits.

Tödtling and Trippl (2005) stress the need to tailor this targeted support to the region, taking into account its specificities. An important element here is the regional policy and strategy. These authors perceive regional innovation systems as a broader concept than clusters that primarily serve to exploit and apply knowledge in one field, while regional innovation systems are a more institutionalized concept that may include multiple clusters from different disciplines in one region.

Mat'átková and Stejskal (2011) provide a detailed look at the composition of regional innovation systems and their layers. They distinguish layer of enterprises, layer of complementary and supportive enterprises, and the environment and infrastructure layer. 
Into the enterprises layer belong companies showing signs of innovative business. The layer of complementary and supportive enterprises include those providing additional and supportive services to the enterprises in the first layer. The layer of environment and infrastructure is then further divided into sub-parts: (a) Environment-shaping institutions (institutions forming the legal framework for entrepreneurship, strategic documents supporting innovative entrepreneurship, network facilitators); (b) Sets of initiatives (public and private initiatives supporting innovative entrepreneurship); (c) Hard and soft infrastructure (industrial zones, technology parks, science and research parks, innovation centres, technology infrastructure research and testing centres and specialized laboratories, knowledge infrastructure universities, and other institutions enabling knowledge transfer).

This arrangement includes private enterprises, research and education institutions and public institutions (local and regional governments). The combination of these three components is known under the term Triple Helix, introduced by Leydesdof and Etzkowitz (1998).

There is considerable agreement the governments and the public sector have the ability to influence the business environment in general, as well as the need for the public sector to play an active role in promoting entrepreneurship and innovation. The role of the public sector in this regard can be significant, both within the above concepts and in many others (Leigh \& Blakely, 2013; Blažek \& Uhlír, 2011).

\subsection{Support of innovations in the framework of strategic planning in the Czech Republic at the regional and municipality level}

Support of business and innovations by the public sector is a global topic. Governments, regions and many municipalities apply several concepts in this respect. Therefore, of course, this topic is also reflected in strategic planning at individual levels of public administration. For example, Skokan (2004) lists among the main areas the focus of regional development strategies selected instruments for business support, business development, human resource development and employment programs; it emphasizes concepts such as achieving regional competitiveness, networking, key competencies, social capital development or strategic leadership.

Grebeníček (2016) addressed the topic of supporting of business and innovations in the framework of regional development strategic planning at regional level in the Czech Republic. Important findings of his work included: (a) The topic of supporting business and innovations is one of the main common development topics of regional development strategic planning. (b) There is considerable heterogeneity among the regions in the models used for strategic planning of regional development, with a focus on promoting business and innovations.

One of the other findings from Grebeníček (2016) in his work mentions the existence of two basic models of strategic planning of regions, namely the two-stage model and three-stage model. In the two-stage model, regions prepare one basic strategic document, which is then followed by individual sector strategies. In the three-step model, the basic long-term strategy is followed by a medium-term development program followed by individual sectoral strategies. The topic of business and innovation support is addressed at all levels in both models. In the case of regional sectoral strategies aimed at promoting entrepreneurship and innovation, documents usually bear the name Regional Innovation Strategy.

The topic of Supporting business and innovations in strategic planning of regional development at municipality level in the Czech Republic was addressed by Grebeníček et al. (2013). Their research was focused on a specific group of regional capitals in the Czech Republic. They analysed the main development strategies of these cities. The main finding was that the topic of business and innovation support is addressed in all analysed strategies, using several typical instruments and activities in this respect. The author's team concluded that supporting business 
and innovations is considered as an important topic by the city authorities. On the other hand, they identified insufficient financial coverage of the declared instruments and activities for the cities concerned.

However, the more narrowly conceived topic of support for innovations at the municipality level in the specific environment of public administration in the Czech Republic has not yet been sufficiently covered by previous research.

\section{METHODOLOGY}

In the introductory phase of the research represented in this paper, the authors focused on the approaches of regional capitals of the Czech Republic to the topic of supporting innovations, declared in the main development strategic documents of these regional capitals. The inclusion of the topic of supporting innovations in the main municipal development strategy indicates an importance of this topic to the municipality and creates preconditions for real systematic action. A specific group of municipalities - regional capitals - was chosen for the initial survey. In terms of conditions of the Czech Republic, regional capitals are large cities. They are members of a group of the largest cities in the country. Their institutional capacity to address the issue of supporting innovations should be better than the institutional capacity of smaller cities and towns in the country. All regional governments in the Czech Republic deal with the topic of supporting innovations with varying degrees of success, both at the level of formalized cooperation with the Ministry of Industry and Trade of the Czech Republic within the National Research and Innovation Strategy for Smart Specialization and at the level of their activities. Regional governments naturally concentrate their activities in the field of supporting innovations within the territories of their regional capital. The spatial proximity of the regional government and the municipality on the one hand and the concentration of the regional government's activities in the territory of its regional capital on the other hand bring these entities into intensive mutual interactions within the topic of supporting innovations. Regional capitals in the Czech Republic have good preconditions to address the topic of supporting innovations from the positions of municipality and for this reason, it is appropriate to focus the initial survey on them.

The research is structured into four research questions:

Q1: Does the regional capitals have valid and approved major development strategies?

Q2: How is the topic of supporting innovations included in the structures of the examined strategies?

Q3: What typical measures, activities and specific instruments made for supporting innovations are set in the main development strategies of regional capitals?

Q4: With what degree of complexity is the topic of innovations support elaborated in the main development strategies of the regional capitals?

Q5: Does supporting innovations represent an important topic which is accentuated by the regional capitals in their main development strategies?

The research is based on the scientific method of document analysis. The main development strategies of regional capitals in the Czech Republic were analyzed by this method. Only valid, approved and published strategies were analyzed. The documents for the research were gathered at the turn of September to October 2019.

Research is based on the scientific method of document analysis. The main development strategies of regional capitals in the Czech Republic were analyzed by this method. Only valid, 
approved and published strategies were analyzed. The documents were gathered for the research at the turn of September and October 2019.

The answers to the research questions were assessed as follows:

Q1: In the first step, it was verified whether the individual Czech regional capitals have valid and approved major development strategy. It was done on the basis of information from a) the online tool "Database of Strategies - Portal of Strategic Documents in the Czech Republic" operated by the Ministry for Regional Development of the Czech Republic and also from, b) content of the regional capital's websites. Subsequently, the proportion of Czech regional capitals meeting this condition was calculated.

Q2: The topic of supporting innovations was assessed within the hierarchical structures of each strategy - whether it appears at the level of vision, set of objectives, a system of measures or as groups of activities. Subsequently, the numbers of occurrence of the topic in the individual assessed levels of strategies were presented.

Q3: Within the group of assessed strategies the objectives, measures, instruments and activities made according to the theoretical background for supporting innovations were identified. Subsequently, they were grouped by species. Based on the frequency of its occurrence across the assessed strategies, the most relevant groups were identified.

Q4: To assess the level of complexity of the topic of supporting innovations in the strategies, a three-tier scale was created: 0 - the topic is not addressed in the strategy; 1 - the topic is included in the strategy, but it is elaborated partially (in a too general form or with using only individual isolated instruments); 2 - the topic is elaborated in the strategy in a specific and systematic form using a set of several instruments and activities. The identification of sub-elements of the topic implemented within the evaluated strategies was made with using of the knowledge of theoretical background. Thereafter, the frequency of occurrence of individual grades of the rating scale was compared.

Q5: The conclusion on the importance of the topic of supporting innovations in the main strategic documents of regional capitals is induced on the basis of answers to the previous questions.

\section{RESULTS}

The research results presented in this chapter are divided into subchapters related to the individual research questions.

\subsection{Group of analysed strategic documents}

The Czech Republic is divided into fourteen regions. This group of regions contains two special cases: a) the City of Prague, which at the same time comprises the functions of municipality and regional government; b) the Central Bohemia Region, which does not have a regional capital - its regional government is based in the city of Prague, meaning outside the territory of the region. For a methodologically consistent approach, these two special cases were removed from the research. The main strategic documents of twelve regional capitals were examined.

The authors apprise as a positive the finding that all regional capitals have already approved main development strategies. In the conclusions of the research conducted by Grebeníček et al. (2013), the absence of the main development strategy was identified in the case of the regional capital Jihlava.

The terminology of the type designation of the strategic documents examined is inconsistent. In the twelve examined cases five different variants occur: (a) strategic development plan (5 
occurrences), (b) development strategy (3 occurrences), (c) strategic plan (2 occurrences), (d) Sustainable Development Strategic Plan (1 occurrence), and (e) strategy (1 occurrence).

The average age of the examined documents after being approved is 5.2 years. However, after taking into account the partial updates of some documents, then it is 3.3 years. These documents can therefore be considered as relevant for evaluating of strategic approaches of the given group of municipalities. An overview of the examined documents is provided in Table 1 below.

Tab. 1 - Overview of the examined documents. Source: own research

\begin{tabular}{|l|l|c|c|c|}
\hline $\begin{array}{c}\text { Regional } \\
\text { capital }\end{array}$ & \multicolumn{1}{|c|}{ Document's title* } & $\begin{array}{c}\text { Term of } \\
\text { approval/update } \\
2007 / 2016\end{array}$ & $\begin{array}{c}\text { End of } \\
\text { validity }\end{array}$ & $\begin{array}{c}\text { Validity } \\
\text { no data }\end{array}$ \\
nears \\
\hline Brno & Strategy for Brno & 2018 & 2027 & 10 \\
\hline $\begin{array}{l}\text { České } \\
\text { Budějovice }\end{array}$ & Strategic Plan of the City of České Budějovice 2017 - 2027 \\
\hline $\begin{array}{l}\text { Hradec } \\
\text { Králové }\end{array}$ & Strategic Development Plan of the City of Hradec Králové 2030 & 2013 & 2030 & 17 \\
\hline Jihlava & $\begin{array}{l}\text { Strategic Development Plan of the Statutory City of Jihlava } \\
\text { 2014-2020 }\end{array}$ & 2014 / 2018 & 2020 & 7 \\
\hline $\begin{array}{l}\text { Karlovy } \\
\text { Vary }\end{array}$ & $\begin{array}{l}\text { Strategic Plan of Sustainable Development of the City of } \\
\text { Karlovy Vary 2014-2020 }\end{array}$ & 2014 & 2020 & 7 \\
\hline Liberec & $\begin{array}{l}\text { Development Strategy of the Statutory City of Liberec 2007- } \\
\text { 2020 }\end{array}$ & $2007 / 2013$ & 2020 & 13 \\
\hline Olomouc & Strategic Development Plan of the City of Olomouc 2017-2023 & 2017 & 2023 & 6 \\
\hline Ostrava & $\begin{array}{l}\text { Strategic Development Plan of the Statutory City of Ostrava } \\
\text { 2017-2023 }\end{array}$ & 2017 & 2023 & 7 \\
\hline Pardubice & Strategic Development Plan of the City of Pardubice 2014-2025 & $2014 / 2017$ & 2025 & 12 \\
\hline Plzeň & Strategic Plan of the City of Pilsen & 2018 & 2035 & 18 \\
\hline $\begin{array}{l}\text { Ústí nad } \\
\text { Labem }\end{array}$ & Development Strategy of the City of Ústí nad Labem 2015-2020 & 2015 & 2020 & 6 \\
\hline Zlín & Development Strategy of the Statutory City of Zlín 2020 & 2012 & 2020 & 9 \\
\hline
\end{tabular}

* Document titles have been translated from Czech to English.

\subsection{Placing the topic of supporting innovations into the structures of examined strategies}

At the highest hierarchical level of the examined strategies, thus at the level of visions, the direct occurrences of the terms connected with the topics of innovation, research and development were identified in seven cases (Brno, České Budějovice, Liberec, Olomouc, Ostrava, Plzeň, Zlín). In the another five cases, an indirect occurrence was identified, represented by terms that assume the existence of a functional innovative ecosystem in the city or region. These are terms such as dynamic development, prosperous economy, advanced economy.

In eleven out of the twelve cases, an occurrence of a separate area or priority aimed at promoting of entrepreneurship, situated in the upper parts of the hierarchical structures of the strategies was identified. The absence was identified only in the case of the Strategic Development Plan of the Statutory City of Ostrava, which is due to a strong integration of topics included in the strategy. This strategy contains only three priority areas situated in the upper part of its hierarchical structure and the topic of promoting entrepreneurship and innovations is situated at one of the lower levels. Specific sub-objectives, measures, activities or instruments related specifically to research, development and innovations occur in all of the examined strategies except the Strategic Development Plan of the Statutory City of Jihlava. In this context, it is necessary to add that the City of Jihlava only adopted its first main development strategy in 2014. This city has the shortest experience with strategic planning at the level of the city's main development strategy. The following table 2 gives an overview of all the main priorities or areas in the examined strategies in which the topic of innovations support is included. 
Tab. 2 - The main development priorities. Source: own research

\begin{tabular}{|c|c|}
\hline Regional capital & $\begin{array}{c}\text { Titles of the main development priorities in the strategic documents in which the topic of } \\
\text { innovations support is included* }\end{array}$ \\
\hline Brno & $\begin{array}{l}\text { Local economic development } \\
\text { Research, development, innovations and education } \\
\text { Image of the city and internal/external relations }\end{array}$ \\
\hline České Budějovice & Business environment, human resources, education, research and innovations \\
\hline Hradec Králové & Business, science, research, innovation \\
\hline Jihlava & Education, business and employment \\
\hline Karlovy Vary & Strengthening the local economy \\
\hline Liberec & Competitive economy and entrepreneurship \\
\hline Olomouc & Competitive and creative Olomouc \\
\hline Ostrava & Wealth in People (integrates multiple topics including Improve Business Development Environment) \\
\hline Pardubice & Economy and life in the city \\
\hline Plzeň & $\begin{array}{l}\text { Develop a promising labor market and link the education system with practice } \\
\text { To raise awareness of Pilsen beyond the city borders and among the citizens of the city }\end{array}$ \\
\hline Ústí nad Labem & Economic development of the city, development and management of the city, external relations \\
\hline Zlín & $\begin{array}{l}\text { Economic development and labor market } \\
\text { Management and administration of the city }\end{array}$ \\
\hline
\end{tabular}

* Titles have been translated from Czech to English.

\subsection{Identified objectives, measures, activities and instruments to support innovations}

The individual strategies from the examined group were prepared in a methodologically inconsistent manner, especially in terms of structure, terminology and degree of detail. This fact reduces the possibility of mutual comparisons of these strategies. Thus, in examining the inclusion of innovation support in these strategies, it has been abstracted from comparisons at the individual levels in the vertical structure. Typical objectives, measures, activities and instruments were sought across all levels in the vertical structures of the individual strategies. An overview of the identified thirteen groups of typical objectives, measures, activities and instruments is shown in Table 3. Based on the frequency of occurrence, two groups that are most important for regional capitals were identified: (a) co-ordinated cooperation between participants in the innovation ecosystem, communication platforms and networking activities, (b) ensuring human resources for research, development and innovations.

Tab. 3 - Typical objectives, measures, activities and instruments to support innovations. Source: own research

\begin{tabular}{|c|c|}
\hline Groups of typical objectives, measures, activities and instruments & Regional capitals \\
\hline Areas and spaces for innovative entrepreneurship & Brno, České Budějovice, Ostrava, Plzeň \\
\hline $\begin{array}{l}\text { Establishment and development of supportive innovations infrastructure - } \\
\text { science and technology parks, technology centres, technology transfer centres, } \\
\text { incubators, co-working centres }\end{array}$ & $\begin{array}{l}\text { Brno, Hradec Králové, Liberec, } \\
\text { Olomouc, Ostrava, Zlín }\end{array}$ \\
\hline Development of clusters and technology platforms for cooperation & Liberec, Olomouc, Ostrava, Plzeň \\
\hline Establishment and development of research centres & Ostrava \\
\hline Support for start-ups & Olomouc, Ostrava, Plzeň, Zlín \\
\hline Innovative voucher programs & Karlovy Vary \\
\hline Comprehensive system of support for investors' attractions & České Budějovice, Ústí nad Labem \\
\hline Ensuring human resources for research, development and innovation & $\begin{array}{l}\text { Brno, České Budějovice, Liberec, } \\
\text { Olomouc, Ostrava, Pardubice, Ústí nad } \\
\text { Labem, Zlín }\end{array}$ \\
\hline $\begin{array}{l}\text { Co-ordinated cooperation between participants in the innovation ecosystem, } \\
\text { communication platforms and networking activities }\end{array}$ & $\begin{array}{l}\text { Brno, České Budějovice, Karlovy Vary, } \\
\text { Liberec, Olomouc, Ostrava, Pardubice, } \\
\text { Plzeň, Ústí nad Labem, Zlín }\end{array}$ \\
\hline The municipality's friendliness towards universities and research organizations & Brno, Liberec, Zlín \\
\hline $\begin{array}{l}\text { Active participation of the municipality in the processes of preparation and } \\
\text { implementation of the regional innovation strategy }\end{array}$ & Liberec, Zlín \\
\hline Internationalization of the local innovative ecosystem & $\begin{array}{l}\text { Brno, Liberec, Olomouc, Plzeň, Ústí } \\
\text { nad Labem }\end{array}$ \\
\hline Promoting of the innovativeness of the city & Brno, Liberec, Olomouc, Plzeň, Zlín \\
\hline
\end{tabular}




\subsection{The level of complexity of innovations support within the regional capitals strategies}

Another assessed aspect of the main development strategies of the regional capitals in the Czech Republic was the complexity of innovations support. In a slight majority ( 7 cases) it was found that the topic is formulated in a systematic and specific form. A minority of strategies ( 5 cases) deal with the topic in partial form (using limited extent of instruments or in too many general declarations). In only one case, the strategy does not include the topic of innovations support at all. Overall, the group of examined strategies evinces a high degree of variability regarding the complexity of innovations support. The classification of the individual regional capital strategies into the levels of the grading scale is shown in Table 4.

Tab. 4 - The levels of complexity of innovations support in individual strategies. Source: own research

\begin{tabular}{|l|l|}
\hline \multicolumn{1}{|c|}{ Level of complexity } & \multicolumn{1}{c|}{ Regional capitals } \\
\hline Level 2 - Specific and systematic elaboration & Brno, České Budějovice, Liberec, Olomouc, Ostrava, Plezň, Zlín \\
\hline Level 1 - Partial elaboration & Hradec Králové, Karlovy Vary, Pardubice, Ústí nad Labem \\
\hline Level 0 - The topic is not addressed & Jihlava \\
\hline
\end{tabular}

\subsection{Assessing the importance of including of the topic of innovations support within the regional capitals strategies}

Except in one case, the topic of innovations support appears in the assessed group of main regional capitals development strategies. Directly or indirectly, it is accentuated at the highest level of the hierarchical structure of these individual strategies - at the level vision. At lower levels, in the systems of objectives, measures, activities and instruments, the topic is included with varying degrees of specificity and complexity. In a slight majority of cases, a detailed systematic approach was identified. Based on these findings, the authors conclude that the inclusion of innovations support in the main development strategies of regional capitals in the Czech Republic represents an important topic for these municipalities, which they seek to understand, grasp and guide.

\section{DISCUSSION AND CONCLUSIONS}

The research helped clarify the topic of innovations support in the framework of the main development strategies of the regional capitals in the Czech Republic. Regional capitals are important participants in the regional innovation systems. They should clarify their roles and attitudes related to the topic of innovations support within their main development strategies following the general principles of strategic planning.

The main development strategies of twelve Czech regional capitals were analyzed. The individual strategies were prepared in a methodologically inconsistent manner, especially in terms of structure, terminology and degree of detail. This fact reduces the possibility of detailed mutual comparisons of these strategies.

Five research questions have been defined in the research and all were fully answered. Their evaluation is briefly presented in the following paragraphs.

Q1: Does the regional capitals have valid and approved major development strategies?

It was found that all Czech regional capitals have already approved main development strategies and all of these strategies are still valid.

Q2: How is the topic of supporting innovations included in the structures of the examined strategies?

Directly or indirectly, it is ordinarily accentuated at the highest level of the hierarchical structure of these strategies - at the level of vision. At lower levels, in systems of objectives, measures, 
activities and instruments, the topic is included in individual strategies with varying degrees of specificity and complexity.

Q3: What typical measures, activities and specific instruments for the supporting innovation are set in the main development strategies of regional capitals?

Thirteen basic groups of specific objectives, measures, activities and instruments have been identified. These are based on the theoretical concept of innovations support within the regional innovation systems. The most important for the Czech regional capitals according to their frequency in the strategies are co-ordinated cooperation between participants in the innovation ecosystem, communication platforms and networking activities, and ensuring human resources for research, development and innovations.

Q4: With what degree of complexity is the topic of innovations support elaborated in the main development strategies of the regional capitals?

It was found that in a slight majority ( 7 cases) the topic is formulated in a systematic and specific form. A minority of strategies (5 cases) deal with the topic in partial form (with using of the limited extent of instruments or in too much general declarations). In only one case, the strategy does not include the topic of innovations support at all.

Q5: Does supporting innovations represent an important topic which is accentuated by the regional capitals in their main development strategies?

The results have shown that innovations support represents the important topic in the main development strategies of the regional capitals in the Czech Republic

The inclusion of the topic of innovations support in the main development strategies of regional capitals represents certain declarations of a future implementation of concrete actions. However, the question arises as to whether or not the declared actions will become real actions in the forms of specific projects or other activities.

In the context of the statement in the introductory literature review about the considerable problematics of implementing of municipal strategies in the Czech Republic, it can be supposed that also the topic of innovations support will be problematic within the implementation phase of the strategy.

Another important issue is the role of municipalities and other participants while implementing strategies. Strategic documents have, among other things, a coordinating function, seeking to harmonize the activities of several participants. Typical groups of specific objectives, measures, activities and instruments have been identified in the individual strategies, but it is not clear what role the municipality and other participants should play in their implementation.

The results of this research responded to important questions on the topic of innovations support from the perspective of regional capitals in the specific environment of the Czech Republic. The authors of the research shall continue to address this topic, which also has strong practical implications.

\section{Acknowledgement}

The authors would like to thank the Internal Grant Agency of FaME for providing financial support to carry out this research. Funding was extended through: TBU No. IGA/FaME/2018/006 Evaluation and efficiency of additional training in companies (SME) in the context of financial resources. 


\section{References}

Blažek, J., \& Uhlír, D. (2011). Teorie regionálního rozvoje: nástin, kritika, implikace. Prague: Karolinum.

Bryson, J. M. (2011). Strategic planning for public and nonprofit organizations: a guide to strengthening and sustaining organizational achievement. San Francisco: Jossey-Bass.

Cooke, P. (1992). Regional innovation systems: Competitive regulation in the new Europe. Geoforum, 23(3), 365-382. doi: 10.1016/0016-7185(92)90048-9

Grebeníček, P. (2016). Podpora podnikání a inovaci v rámci strategického plánování regionálního rozvoje. Zlín: Tomas Bata University in Zlín.

Grebeníček, P., \& Hájek, O. (2013). K tématu strategického plánování regionálního rozvoje. Urbanismus a územní rozvoj, XVI(4), 21-26. Retrieved from https://www.uur.cz/images/5-publikacni-cinnost-a-knihovna/casopis/2013/201304/03_k\%20tematu.pdf

Grebeníček, P. Hájek, O., Smékalová, L, \& Danko, L. (2013). Support of business and innovations in strategic planning of regional development on the municipal level of the Czech Republic. Acta Universitatis Agriculturae et Silviculturae Mendelianae Brunensis, 61(7), 2143-2149. doi: 10.11118/actaun201361072143

Habuda, M. (2013). Hodnoceni současné praxe strategického plánování rozvoje ve městech s více než 50000 obyvateli na území České republiky. Paper presented at the 13th Conference of Postgraduate Students and Young Scientists in Informatics, Management, Economics and Administration, Pardubice, Czech Republic. Pardubice: University of Pardubice.

Ježek, J. (2014). Plánovací kultura v České republice na př́kladu strategického plánování měst. Trendy v podnikání: vědecký časopis Fakulty ekonomické ZČU v Plzni, 4(4), 52-57. Retrieved from http://www.fek.zcu.cz/tvp/doc/akt/tvp-4-2014-clanek-7.pdf

Ježek, J. et al. (2015). Strategické plánování obcí, měst a regioni̊: vybrané problémy, výzvy a možnosti řě̌ení. Prague: Wolters Kluwer.

Leigh, N. G., \& Blakely, E. J. (2013). Planning local economic development: theory and practice. Los Angeles: Sage.

Leydesdorff, L., \& Etzkowitz, H. (1998). The Triple Helix as a model for innovation studies. Science and Public Policy, 25(3), 195-203. doi: 10.1093/spp/25.3.195

Malmberg, A. (1997). Industrial geography: location and learning. Progress in Human Geography, 21(4), 573-582. doi: 10.1191/030913297666600949

Maskell, P. (1998). Low-Tech Competitive Advantages and the Role Of Proximity: The Danish Wooden Furniture Industry. European Urban and Regional Studies, 5(2), 99-118. doi: 10.1177/096977649800500201

Mat'átková, K., \& Stejskal, J. (2011). Znaky regionálních inovačních systémů. Scientific Papers of the University of Pardubice - Series D, 22(4), 133-142. Retrieved from https://dk.upce.cz/handle/10195/42687

Novák, D. W. (2010). Strategické plány rozvoje obcí a regionů a hodnocení jejich kvality. In V. Klímová (Ed.), XIII. Mezinárodni kolokvium o regionálních vědách. Brno: Masaryk University. 
Řehoř, P. (2015). How to Improve Strategic Planning of Municipal Organizations in Czech Republic? Procedia Economics and Finance, 34, 521-527. doi: 10.1016/S22125671(15)01663-9

Skokan, K. (2004). Konkurenceschopnost, inovace a klastry v regionálním rozvoji. Ostrava: Repronis.

Slach, O., \& Ježek, J. (2015). The State of the Art of Planning in Europe - Czechia. disP - The Planning Review, 51(1), 28-29. doi: 10.1080/02513625.2015.1038050

Tödtling, F., \& Trippl, M. (2005). One size fits all?: Towards a differentiated regional innovation policy approach. Research Policy, 34(8), 1203-1219. doi: 10.1016/j.respol.2005.01.018

Truneček, J. (2004). Management znalostí. Prague: C. H. Beck.

Vozáb, J. (1999). Strategické plánování rozvoje měst v České republice. Prague: Charles University.

\section{Contact information}

\section{Ing. et Ing. Martin Habuda}

Tomas Bata University in Zlín, Faculty of Management and Economics Mostní 5139, 76001, Zlín, Czech Republic

E-mail: habuda@utb.cz

ORCID: 0000-0002-5291-0466

\section{Ing. Mgr. Ladislav Kudláček}

Tomas Bata University in Zlín, Faculty of Management and Economics Mostní 5139, 76001, Zlín, Czech Republic

E-mail: 1kudlacek@utb.cz

ORCID: 0000-0001-7375-0388

doc. PhDr. Ing. Aleš Gregar, CSc.

Tomas Bata University in Zlín, Faculty of Management and Economics Mostní 5139, 76001, Zlín, Czech Republic

E-mail: gregar@utb.cz

ORCID: 0000-0001-9939-5222

doi: 10.7441/dokbat.2019.030 